Volume II, No.2 Desember 2012/1433 H

\title{
EKSPLORATIF TINGKAT PRODUKTIVITAS AGEN PEMASAR PT. ASURANSI JIWA BUMI ASIH JAYA DISTRIK DEMANGAN CABANG JATENG
}

\author{
Ahmad Yunadi \\ (Dosen STIA Alma Ata Yogyakarta)
}

\begin{abstract}
This study entitled "Eksplorative Study of Productivity Level by Marketing Agent of PT. Asuransi Jiwa Bumi Asih Jaya District Demangan Branch Central Java". PT. Asuransi Jiwa Bumi Asih Jaya District Demangan Branch Central Java is a company engaged in life insurance services. This study aims to determine the level of productivity and the factors that support the productivity of marketers such as recruitment/selection, training, job satisfaction and leadership.

The results showed that all factors such as recruitment/selection, training, job satisfaction and leadership could support the success of the company with a good level of productivity. This is proved by increased of sales policy in every year. PT. Asuransi Jiwa Bumi Asih Jaya District Demangan Branch Central Java do marketing agent recruitment with the involvement of psychologists to get individual characters such enormous interest to sell, talent, intelligence, broad knowledge and ways of communication to others, never give up, persevere and have the character of leaders. Then held training from PAMO, PAG, PAS and the PUM with materials that support the sale of policies and materials on familiar characters on the leader himself. Job satisfaction also appears to marketers when a close relationship between the leader and marketer, as well as between fellow marketers, besides giving provision which consistent with productivity at work. Leadership done by PT. Asuransi Jiwa Bumi Asih Jaya District Demangan Branch Central Java has been very good where marketers provide an appreciation of his leadership and zeal in work. Advised to the company to keep using the recruitment/selection, training, job satisfaction and leadership that already exists to further improve the productivity of marketing agents.
\end{abstract}

Keyword: Productivity, Marketing, Agent, insurance.

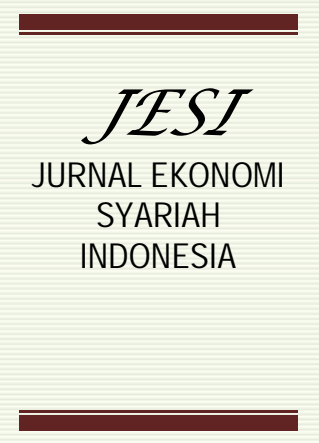

\section{A. LATAR BELAKANG}

Lembaga Asuransi sebagai lembaga keuangan non Bank (Triandaru, 2006: 177) merupakan lembaga yang memiliki peranan yang cukup besar dalam perekonomian suatu negara yakni untuk memobilisasi keuangan negara melalui produk jasa yang dihasilkan oleh lembaga atau perusahaan asuransi. Perusahaan Asuransi berhasil menghimpun dana masyarakat dalam bentuk premi untuk diinvestasikan kembali agar menghasilkan barang dan jasa. Lembaga Asuransi dalam operasionalnya dapat membantu Pemerintah dalam pembangunan, penciptaan lapangan 
kerja, berperan dalam menekan laju inflasi, serta merupakan lembaga gotong royong masyarakat secara modern.

Di negara-negara yang sudah maju perekonomiannya serta pemahamannya terhadap asuransi pada umumnya sebagian besar dari penduduknya memiliki polis asuransi baik asuransi jiwa maupun asuransi kerugian, hal tersebut dapat dipahami karena mereka disamping telah memiliki kesadaran berasuransi yang tinggi, daya beli masyarakat, dan ditunjang dengan manajemen perusahaan asuransi yang dapat dipercaya (credible). Dari pengalaman penulis mengikuti seminar "Mengembangkan Asuransi Jiwa melalui Agen Pemasar" pada bulan Juli 2009, tercatat 83\% dari penduduk Negara Taiwan memiliki polis Asuransi Jiwa. Sangat jauh dibandingkan dengan negara Indonesia baru 29\% dari penduduk Indonesia yang telah memiliki polis Asuransi jiwa. Banyak faktor yang dapat mempengaruhi perkembangan usaha asuransi di suatu negara, baik faktor lingkungan eksternal maupun lingkungan internal.

Dari berbagai faktor tersebut mempengaruhi laju pertumbuhan asuransi khususnya asuransi jiwa di Indonesia masih sangat terbelakang dibandingkan dengan negara-negara lainnya. untuk mempersempit permasalahan penulis mencoba untuk lebih mengkonsentrasikan kepada permasalahan sumberdaya manusia yang berada dalam lngkungan perusahaan itu sendiri dan khususnya yang berada pada PT. Asuransi Jiwa Bumi Asih Jaya Distrik Demangan Cabang Jateng di Yogyakarta. Berkaitan dengan itu, keberadaan sumberdaya manusia yang memiliki tingkat kompetensi yang tinggi bagi perusahaan menjadi kebutuhan yang sangat mendasar. Kompetensi tersebut dapat dicapai melalui upaya mengembangkan secara koperehensif kemampuan para pemasar untuk mengambil keputusan-keputusan strategis dalam meningkatkan produktivitas.

Seorang pemasar asuransi, disamping memiliki kualitas ilmu pengetahuan seorang pemasar asuransi saat ini dituntut memiliki sikap toleransi pada pendapat-pendapat yang berbeda/ganda/ambigu, proaktif, berjiwa interpreuneur, kebergantungan kooperatif, integrasi virtual, fokus pada lingkungan yang kompetitif, memiliki keuntungan investasi yang stabil, dan dapat menciptakan pasar pada masa yang akan datang (tolerance of ambiquity, proactive, enterpreneurial, coorporative interpendence, virtual integration, vocus on copetitive environment, constant reinvention advantage dan creating tomorrow's market) (Djamaluddin Ancok, 2001). Sementara Stephen Rhinesmith mengemukakan adanya enam wawasan global yang harus dimiliki, yaitu:

1. Mempunyai wawasan yang luas dan selalu melihat sesuatu dalam kompleks.

2. Menyadari bahwa kehidupan dunia itu serba kompleks dan penuh dengan kekuatan-kekuatan yang kontradiktoris sehingga memerlukan kemampuan manajemen konflik.

3. Menghargai lebih pada proses organisasi daripada struktur hirarkis Ahmad Yunadi formal.

4. Menghargai kerja sama multi kultural dan keraganran, fleksibilitas dan kepekaan.

5. Melihat perubahan-peruballan sebagai kesempatan (opportunities).

JURNAL EKONOMI SYARIAH INDONESIA, Volume II, No.2 Desember 2012 
6. Terus menerus mempertajam keabsahan paradigmanya sendiri (H.A.R Tilaar, 2001:37).

\section{B. Fokus Penelitian}

Untuk lebih mempersempit faktor-faktor yang akan diteliti dan ditelaah, maka batasan-batasan yang akan dibahas dalam penelitian ini adalah:

1. Produktivitas Agen Pemasar di PT. Asuransi Jiwa Bumi Asih Jaya Distrik Demangan Cabang Jateng

2. Rekruitment Agen Pemasar di PT. Asuransi Jiwa Bumi Asih Jaya Distrik Demangan Cabang Jateng

3. Pelatihan bagi Agen Pemasar di PT. Asuransi Jiwa Bumi Asih Jaya DistrikDemangan Cabang Jateng

4. Kepuasan Kerja Agen Pemasar PT. Asuransi Jiwa Bumi Asih Jaya Distrik Demangan Cabang Jateng

5. Kepemimpinan bagi Agen Pemasar PT. Asuransi Jiwa Bumi Asih Jaya Distrik Demangan Cabang Jateng

\section{Rumusan Masalah}

Berdasarkan kepada teori yang ada serta kondisi yang ada pada perusahaan, penulis mencoba untuk merumuskan masalah:

1. Bagaimana Produktivitas Agen Pemasar PT. Asuransi Jiwa Bumi Asih Jaya Distrik Demangan Cabang Jateng?

2. Bagaimana Rekruitment Agen Pemasar PT. Asuransi Jiwa Bumi Asih Jaya Distrik Demangan Cabang Jateng?

3. Bagaimanakah Pelatihan yang diberikan bagi Agen Pemasar di PT. Asuransi Jiwa Bumi Asih Jaya Distrik Demangan Cabang Jateng?

4. Bagaimanakah Kepuasan Kerja Agen Pemasar PT. Asuransi Jiwa Bumi Asih Jaya Distrik Demangan Cabang Jateng?

5. Bagaimanakah Kepemimpinan bagi Agen Pemasar PT. Asuransi Jiwa Bumi Asih Jaya Distrik Demangan Cabang Jateng?

\section{Tujuan Penelitian}

Tujuan dari penelitian ini adalah:

1. Untuk mencari dan mengumpulkan data yang relefan untuk mengetahui faktor-faktor yang berkaitan dengan tingkat produktivitas agen pemasar PT. Asuransi Jiwa Bumi Asih Jaya Distrik Demangan Cabang Jateng.

2. Untuk mengetahui sejauh mana faktor rekruitment, pelatihan, kepuasan kerja serta kepemimpinan secara individual dapat menunjang tingkat produktivitas agen pemasar.

\section{E. Manfaat Penelitian}

1. Menjelaskan faktor-faktor yang menunjang tingkat produktivitas tenaga pemasar yaitu rekruitment, pelatihan, kepuasan kerja serta kepemimpinan.

Study

Eksploratif

215
2. Bagi Perusahaan Asuransi umumnya serta PT. Asuransi Jiwa Bumi Asih Jaya khususnya agar lebih dapat mengambil keputusan yang ada hubungannya dengan produktivitas pemasar.

3. Bagi penulis diharapkan penelitian ini bermanfaat untuk menerapkan teori-teori yang dipelajari dalam perkuliahan di kelas

JURNAL EKONOMI SYARIAH INDONESIA, Volume II, No.2 Desember 2012 
dengan kenyataan yang ada serta yang terpenting adalah sebagai persyaratan untuk mendapatkan gelar kepascasarjanaan.

\section{F. LANDASAN TEORI}

\section{Manusia Sebagai Obyek dan Subyek}

Menurut Darmayuda (2002:23) menjelaskan bahwa manusia sebagai makhluk yang memiliki kedudukan tertinggi di antara makhluk makhluk lainnya, memiliki kemampuan untuk mengadakan perubahanperubahan agar terjadi perbaikan taraf kehidupan, menciptakan kebutuhan serta memenuhi kebutuhan sehingga terjadi suatu dinamisme yang mengarah kepada perbaikan-perbaikan dari yang dirasakan sebelumnya, terus mengeksplorasi sumberdaya yang terbatas untuk memenuhi kebutuhan yang tidak terbatas. Dalam kedudukannya sebagai subyek manusia secara terus menerus mengupayakan untuk menggali sumber sumber yang berada di luar manusia baik itu sumber daya alam, sumber daya materiil kebendaan sumber daya uang, sumber daya waktu dan lain sebagainya untuk diolah menjadi sumber daya baru yang lebih efektif dan lebih efisien atau dengan kata lain terus berupaya untuk meningkatkan produktivitas.

Dalam kedudukannya sebagai subyek manusia juga merupakan potensi yang dapat digali baik dari segi psikis maupun dilihat dari segi fisiknya, misalnya dari segi psikisnya pada diri manusia terdapat sifat sifat, bakat, pembawaan, kepribadian dan lainnya yang semua itu adalah merupakan potensi yang dapat dimanfaatkan, suatu contoh seseorang memiliki bakat melukis, jika potensi tersebut digali dan dikembangkan maka akan dapat menghasilkan yang bernilai tinggi, demikian juga halnya dengan kekuatan fisik manusia menghasilkan berupa tenaga yang apabila tenaga tersebut diberdayakan dapat menghasilkan produk ataupun jasa yang sangat bermanfaat bagi manusia itu sendiri maupun bagi manusia yang lainnya. Jadi pada dasarnya manusia sebagai makhluk ciptaan Tuhan yang tertinggi derajatnya dapat menggali kekuatan dari diri manusia itu sendiri juga dapat menggali kekuatan yang ada di luar diri manusia.

\section{Manajemen Sumber Daya Manusia}

Determinan utama keberhasilan sebuah organisasi adalah bagaimana memperoleh, memelihara dan mempertahankan sumber daya manusianya. Untuk menggerakkan berbagai sumber daya organisasi sangat tergantung pada seberapa besar sumber daya manusia yang dimiliki. Organisasi hanya merupakan satu wadah untuk mencapai tujuan dan manusialah yang akan membawa organisasi tersebut mencapai tujuannya. Oleh karena itu sumber daya manusia merupakan aset yang harus mendapat perhatian paling tidak harus sama sebagaimana halnya dengan sumber daya lainnya. Pabrik, perlengkapan, dan aset-aset finansial adalah sumber-sumber daya yang dibutuhkan organisasi, akan tetapi orang-orang yakni sumber daya manusia adalah sangat penting.

Menyadari peran strategis sumber daya manusia maka setiap manajer organisasi harus memahami apa yang disebut dengan manajemen sumber daya manusia. Melalui manajemen sumber daya manusia membantu para manajer untuk pengambilan keputusan, baik yang

Ahmad

Yunadi

216 berkaitan dengan perluasan produksi, ataupun untuk mengejar peluang yang kemungkinan dapat dicapai. Dalam hal ini manajemen sumber daya 
manusia tidak memandang karyawan sebagai modal yang mengandung konsekuensi biaya, melainkan dianggap sebagai sumber daya organisasi yang dapat meningkatkan keunggulan kompetitif organisasi.

Manajemen (management) adalah proses pengelolaan atau pendayagunaan bahan baku dan sumber daya manusia untuk mencapai tujuan-tujuan yang ditetapkan. Proses ini melibatkan organisasi, arahan, koordinasi dan evaluasi orang-orang guna mencapai tujuan-tujuan tersebut. Sehingga esensi yang dapat dipahami dari manajemen adalah aktivitas bekerja sama dengan orang lain agar mencapai pengintegrasian berbagai sumber daya dan tugas untuk mencapai tujuan organisasi yang telah ditentukan.

Dalam organisasi perusahaan asuransi sumber daya manusia sering disebut pemasar yaitu karyawan yang melaksanakan tugas-tugas pemasaran yang menjual dan mempromsikan produk dari perusahaan. Sehingga penggunaan istilah sumber daya manusia berkenaan dengan orang-orang di dalam organisasi yang menjalankan tugas dan fungsinya terhadap perusahaan (Al Fajar dan Tri Heru, 2010:3). Searah dengan pendapat ini, Nawawi (2001:37) melihat arti SDM atas tiga sudut, yaitu:

1. SDM adalah orang yang bekerja dan berfungsi sebagai aset organisasi/ perusahaan yang dapat dihitung (kuantitas). Dalam pengertian ini fungsi SDM tidak berbeda dengan fungsi aset lainnya, sehingga dikelompokkan dan disebut sebagai sarana produksi, sebagaimana sebuah mesin, komputer (sumber daya teknologi), investasi (sumber daya finansial), gedung, mobil (sumber daya matrial), dll.

2. SDM adalah potensi yang menjadi motor penggerak organisasi/ perusahaan. Setiap SDM berbeda-beda potensinya, maka kontribusinya dalam bekerja untuk mengkonkritkan Rencana Operasional Bisnis menjadi kegiatan bisnis tidak sama satu dengan yang lain.

3. Manusia sebagai sumber daya adalah makhluk ciptaan Tuhan YME, sebagai penggerak organisasi/ perusahaan berbeda dengan sumber daya lainnya. Nilai-nilai kemanusiaan yang dimilikinya, mengharuskan sumber daya manusia diperlakukan secara berlainan dengan sumber daya lainnya. Dalam nilai-nilai kemanusiaan itu terdapat potensi berupa ketrampilan dan keahlian, kepribadian termasuk harga diri, sikap, motivasi kebutuhan dll yang mengharuskan dilakukan perencanaan SDM agar SDM yang dipekerjakan sesuai dengan kebutuhan organisasi/ perusahaan.

\section{Produktivitas}

Masalah produktivitas adalah merupakan suatu hal yang sangat menarik dan terus menjadi pembahasan bagi seseorang, organisasi, lembaga-lembaga bahkan merupakan permasalahan bangsa, karena

Study

Eksploratif

217
Bangsa atau Negara menjadi maju dan berkembang hanya jika ditunjang oleh produktivitas bangsa itu sendiri, Kenapa negara Jepang, Negara Korea, Hongkong, Cina, Singapura dan Negara negara maju lainnya baik ditingkat Asia, terlebih lagi Negara Barat (Eropa) dimana kalau dilihat dari sumber daya terutama sumber daya alam mereka tidak memiliki sumber daya alam yang melimpah, ternyata kuncinya adalah permasalahan

JURNAL EKONOMI SYARIAH INDONESIA, Volume II, No.2 Desember 2012 
produktivitas Bangsa tersebut. Banyak hal yang mempengaruhi taraf hidup serta kualitas hidup, mengatasi masalah ketenagakerjaan mempengaruhi pertumbuhan ekonomi Negara, ekspor, inflasi, kesehatan usaha karena efisiensi demikian saling mempengaruhi secara integrate sehingga permasalahan arti, pengertian hakekat yang berhubungan dengan produktivitas harus terus dikaji, dianalisa secara seksama secara akurat dan terus menerus dilakukan karena kondisi lingkungan yang terus berubah.

Menurut George J. Washinis (Rusli Syarif,1991:1) bahwa "Produktivitas mencakup dua konsep dasar yaitu daya guna dan hasil guna. Daya guna menggambarkan tingkat sumber-sumber manusia, dana, dan alam yang diperlukan untuk mengusahakan hasil tertertu, sedangkan hasil guna menggambarkan akibat dan kualitas dari hasil yang diusahakan". Lain halnya dengan pendapat yang dikemukakan oleh Sinungan bahwa: "Produktivitas adalah merupakan tingkat perbandingan antara keluaran (output) dengan masukan (input) dikaitkan dengan sasaran yang diinginkan" (Sinungan, 2000:12).

Pada tingkat perusahaan, pengukuran produktivitas digunakan sebagai sarana manajemen untuk menganalisa dan mendorong efisiensi produksi, hal mana berdasarkan pemikiran bahwa selain sumber daya alam, tehnologi, sumber daya manusia merupakan unsur yang sangat menentukan keberhasilan dalam proses produksi suatu organisasi, karena perusahaan tersebut akan kalah dalam persaingan jika perusahaan tersebut kurang atau tidak produktif. Sumber daya yang ada harus dapat dimanfaatkan secara optimal.

Terdapat 3 (tiga) hal yang melekat dalam produktivitas yaitu:

1. Adanya efisiensi, artinya seberapa besar tingkat efisiensi dalam menggunakan sumberdaya yang digunakan dalam proses produksi untuk menghasilkan produk atau jasa. Efisiensi merupakan karakteristik proses yang mengukur aktual dari sumberdaya yang relatif terhadap standar yang ditetapkan.

2. Efektivitas, merupakan karakteristik lain dari proses yang mengukur derajat pencapaian output dari sistem produksi yang artinya pengukuran terhadap kenyataan dari output yang direncanakan.

3. Fleksibilitas, yakni merupakan karakteristik dari proses yang mengukur seberapa lama proses untuk menghasilkan output yang berbeda.

\section{Manfaat dari Pengukuran Produktivitas}

Untuk mengukur suatu produktivitas perusahaan dapatlah digunakan dua jenis ukuran jam kerja manusia, yakni jam-jam kerja yang harus dibayar dan jam-jam kerja yang dipergunakan untuk bekerja. Jam kerja yang harus dibayar meliputi semua jam-jam kerja yang harus dibayar, ditambah jam-jam yang tidak digunakan untuk bekerja namun harus dibayar, liburan, cuti, libur karena alasan yang mendesak, tugas luar dan sisa lainnya. Jadi bagi keperluan pengukuran umum produktivitas tenaga kerja itu memiliki unit-unit yang diperlukan, yakni: kuantitas hasil dan kuantitas penggunaan masukan tenaga kerja

Ahmad

Yunadi

218

Suatu organisasi perusahaan sangat penting mengetahui pada tingkat mana produktivitas yang dicapai disetiap bagian untuk dibandingkan dengan 
produktivitas standart yang ditetapkan manajemen, mengukur produktivitas dari waktu ke waktu, membandingkan dengan produktivitas industri yang menghasilkan produk yang sejenis, hal ini adalah sangat penting yakni agar organisasi perusahaan dapat meningkatkan daya saingnya dari produk yang dihasilkan.

\section{Peningkatan Produktivitas}

Suatu organisasi perusahaan didirikan tentu memiliki suatu tujuan dan harapan apa yang akan dicapai oleh organisasi perusahaan tersebut sebagai arah dan dalam mewujudkan tujuan tersebut melakukan berbagai upaya dengan norma serta kaidah di lingkungan dimana organisasi perusahaan tersebut berada, melakukan inovasi-inovasi, melakukan penghematan, menciptakan cara-cara yang efektif yang semuanya ditujukan untuk mencapai tingkat produktivitas yang tinggi. Menurut Almigo (2004) "Interaksi organisasi perusahaan dengan lingkungan akan sangat menentukan keberhasilan organisasi tersebut, sebab bagaimanapun faktor-faktor kekuatan internal dimiliki tetapi jika faktor lingkungan eksternalnya tidak memberikan peluang untuk mencapai tujuan organisasi perusahaan".

Jika dilihat dari pendekatan sistem maka keberhasilan dalam peningkatan produktivitas tidak akan dapat terlepas dari lingkungan internal maupun lingkungan eksternal. Pendekatan sistem berarti terdapat beberapa unsur, atau bagian lingkungan dimana masing-masing unsur berinteraksi dan berintegrasi untuk mencapai suatu tujuan. Dilihat dari konteks ini maka dalam peningkatan produktivitas akan dipengaruhi oleh faktor -faktor seperti:

1. Faktor Manusianya

2. Faktor Modal

3. Faktor Methode/Proses

4. Faktor Produksi yang dihasilkan

5. Faktor Lingkungan Organisasi Perusahaan

6. Faktor Lingkungan Negara (eksternal)

\section{Produktivitas Pemasar Asuransi Jiwa}

Pengukuran produktivitas karyawan dalam hal ini pemasar asuransi jiwa harus terus dikembangkan untuk dapat mencapai efektivitas, efisiensi maupun optimalisasi sejalan dengan terjadinya perubahanperubahan lingkungan terutama semakin tingginya tingkat persaingan yang menuntut produktivitas yang semakin tinggi dari organisasi perusahaan, demikian pula tentu halnya dengan industri asuransi jiwa sebagai lembaga yang mempunyai peranan cukup besar harus terus mengupayakan peningkatan produktivitas organisasi melalui peningkatan sumberdaya manusia dalam hal ini para pemasar asuransi jiwa.

Dengan berbagai faktor lingkungan yang mempengaruhi

Study

Eksploratif

219 produktivitas kerja, dan berdasarkan pengamatan secara langsung penulis terhadap para pemasar asuransi jiwa Bumi Asih Jaya di Yogyakarta dari sekian banyak faktor, maka penulis mencoba untuk mempersempit permasalahan produktivitas pemasar asuransi jiwa dari 5 (lima) kategori yakni: dari sudut rekruitment, pelatihan, karakteristik individu pemasar, kepuasan kerja, serta pemberian upah. Seperti penulis amati bahwa tidak 
banyak orang yang tertarik akan profesi, karier menjual asuransi jiwa dan sekian yang berhasil sukses dalam karier ini ternyata banyak dan lebih banyak yang gagal dalam perjalanan kariernya, sehingga dengan latar belakang rumusan masalah diharapkan sedikitnya memberikan suatu gambaran tentang tingkat produktivitas para pemasar asuransi jiwa.

\section{Rekruitment/ Seleksi}

Rekruitment merupakan salah satu fungsi manajemen personalia yang dilakukan setelah penentuan formasi. Hal ini penting karena melalui penentuan formasi akan diketahui kebutuhan organisasi terhadap sumber daya manusia, Untuk menyusun formasi yang tepat terlebih dahulu disusun analisa kebutuhan pegawai yaitu suatu proses analisa secara logis dan teratur untuk dapat mengetahui jumlah dan kualitas pegawai yang diperlukan oleh sesuatu unit organisasi.

Untuk memperoleh tenaga kerja yang bermutu tinggi maka menurut Siagian (2009:134) proses rekrutmen harus memperhatikan faktor etika dan faktor kesamaan kesempatan. Faktor etika menghendaki ditegakannya norma-norma etika antara lain disiplin pribadi, kejujuran, integritas karakter serta objektivitas yang didasarkan pada kriteria yang jelas. Hal ini sangat penting karena tidak mustahil perekrut dihadapkan kepada berbagai macam godaan, seperti menerima hadiah, disogok oleh pelamar, mengkatrol nilai seleksi dari pelamar yang mempunyai hubungan darah atau kaitan primordial lainnya yang mengakibatkan seseorang perekrut mengambil keputusan yang didasarkan pada pertimbangan subjektif. Sering terjadi ada pelamar yang "mendapat perhatian khusus" atau "titipan" dari pimpinan tingkat atas. Dalam hal ini menjadi persoalan adalah jika titipan tersebut tidak berkualitas, akibatnya organisasi mempekerjakan bukan pelamar terbaik. Situasi ini sering dihadapi organisasi dalam masyarakat yang berbagai ikatan primordialnya, seperti kesukuan, kedaerahan, masih kuat disamping masih berlakunya extended family system.

\section{Pelatihan}

Masyarakat masa depan adalah masyarakat yang didasarkan pada kemampuan (merit system) dan bukan berdasarkan pada fasilitas dari kekuasaan. Kompetisi yang terjadi lebih banyak berlangsung pada tataran ilmu pengetahuan dan teknologi. Hanya orang-orang yang berkualitas saja yang mampu membaca peluang-peluang dalam perubahan lingkungan yang begitu cepat. Dengan demikian pengembangan dalam arti meningkatkan pengetahuan dan kemampuan karyawan mutlak dilaksanakan.

Pentingnya pengembangan karyawan mengingat tuntutan pekerjaan dan jabatan sebagai akibat kemajuan teknologi dan ketatnya persaingan (Hasibuan, 2008:68). Menurut Hasibuan pengembangan harus bertujuan meningkatkan kemampuan teknis, teoritis, konseptual dan moral karyawan supaya prestasi kerjanya baik dan mencapai basil yang optimal. Upaya peningkatan kualitas ini dilakukan dalam bentuk pelatihan dan pengembangan (Simamora, 2006:273).

\section{Kepuasan Kerja}

Manusia sebagai subyek dalam lingkungan adalah merupakan faktor penentu pencapaian kebutuhan atau tujuan organisasi, emosi

\section{Ahmad \\ Yunadi}


manusia akan merupakan dasar motivasi bagi seseorang untuk mencapai prestasi. Kepuasan adalah merupakan salah satu dari emosi manusia, karena jika seseorang merasa puas maka seseorang akan menjadi bersemangat, dan jika seseorang bersemangat maka ia akan bekerja keras dan akhirnya berprestasi.

Pendapat lain dikemukakan oleh Wexley dan Yukl mengartikan bahwa kepuasan kerja sebagai "the way an employee feels about his or her job". Artinya bahwa kepuasan kerja adalah cara karyawan merasakan dirinya atau pekerjaannya. dapat disimpulkan bahwa kepuasan kerja adalah perasaan yang menyokong atau tidak menyokong dalam diri karyawan yang berhubungan dengan pekerjaan maupun kondisi dirinya. Perasaan yang berhubungan dengan pekerjaan melibatkan aspek-aspek seperti upaya, kesempatan pengembangan karier, hubungan dengan pegawai lain, penempatan kerja, dan struktur organisasi. Sementara itu, perasaan yang berhubungan dengan dirinya antara lain berupa umur, kondisi kesehatan, kemampuan dan pendidikan. Sedangkan Stephen Robins mengemukakan bahwa kepuasan itu terjadi apabila kebutuhan-kebutuhan individu sudah terpenuhi dan terkait dengan derajat kesukaan dan ketidaksukaan dikaitkan dengan Pegawai, merupakan sikap umum yang dimiliki oleh Pegawai yang erat kaitannya dengan imbalan-imbalan yang mereka yakini akan mereka terima setelah melakukan sebuah pengorbanan.

Faktor-faktor kepuasan kerja menurut Gilmer yang dikutif M As'ad dalam bukunya Psikologi Industri halaman 114 menjelaskan bahwa faktor kepuasan kerja dipengaruhi oleh:

a. Kesempatan untuk maju

b. Keamanan Kerja

c. Gaji dan Kompensasi/Upah

d. Perusahaan dan Manajemen

e. Pengawasan (Supervisi)

f. Faktor Intrinsik dari Pekerjaan

g. Kondisi kerja

h. Aspek sosial dalam pekerjaan

i. Komunikasi.

j. Fasilitas.

\section{Kepemimpinan}

Kepemimpinan adalah suatu proses dimana pimpinan/pemimpin dapat mempengaruhi bawahannya/orang lain, agar bawahan/orang lain tersebut mau melakukan apa yang diinginkan oleh pimpinan/pemimpin tersebut. Gaya kepemimpinan adalah cara yang digunakan pimpinan/pemimpin dalam mempengaruhi bawahan/orang lain, agar tercapai apa yang diinginkannya.

Study

Eksploratif

221

Selanjutnya Gitosudarmo dan Mulyono (1990:30) mengatakan bahwa seorang pemimpin yang profesional adalah pemimpin yang mampu menciptakan atau membuat kedua belah pihak menjadi senang, bahagia dan bangga. Untuk merealisasikan hal tersebut, maka seorang pemimpin harus mempunyai gaya kepemimpinan yang tepat, agar dapat mencapai tujuan organisasi secara efektif. Sedangkan Hasibuan mengatakan bahwa

JURNAL EKONOMI SYARIAH INDONESIA, Volume II, No.2 Desember 2012 
pemimpin adalah seseorang yang mempergunakan wewenang dan kepemimpinannya mengarahkan bawahan untuk mengerjakan sebagian pekerjaannya dalam mencapai tujuan organisasi. Sedangkan kepemimpinan adalah cara atau gaya seorang pemimpin mempengaruhi perilaku bawahan, agar mau bekerja sama dan bekerja secara produktif untuk mencapai tujuan organisasi. (Hasibuan, 2000; 167). Dalam setiap kepemimpinan ada dua pola dasar kepemimpinan, yaitu pola dasar kepemimpinan formal dan pola dasar kepemimpinan informal (Yayat M. Herujito, 2004:181)

a. Pola Kepemimpinan Formal

b. Pola Kepemimpinan Informal

\section{G. Penelitian Sebelumnya}

Disini, peneliti akan membahas penelitian terdahulu yang berkaitan dengan konsep penelitian ini. Penelitian yang dimaksud yaitu penelitian oleh Puteri Dyah Ayu Puspitasari, Fakultas Ekonomi yang berjudul "Analisis Produktivitas Kerja Pemasar pada PT. Telkomsel di Yogyakarta". Objek dari penelitian ini adalah manajemen sumber daya manusia yang bertujuan untuk menggambarkan produtivitas kerja pemasar pada PT. Telkomsel di Yogyakarta

Tujuan penelitian tersebut adalah untuk mengetahui faktor-faktor yang mempengaruhi produktivitas yang dilakukan PT. Telkomsel dalam meningkatkan produktivitas di Yogyakarta, Metode yang digunakan adalah metode kualitatif. Metode kualitatif adalah metode yang tidak mencari atau menjelaskan hubungan, tidak menguji hipotesa atau membuat prediksi (Surakhmad, 1998: 139). Hasil penelitian tersebut, kelima batasan masalah yang digunakan Telkomsel dalam meningkatkan produktivitas kerja pemasarnya seperti terlihat dibawah ini:

1. Motivasi $\longrightarrow$ peran atasan dalam member pengarahan bawahannya.

2. Pelatihan $\longrightarrow$ menyelenggarakan pelatihan mulai dari tingkat dasar (basic), pelatihan agen dan pelatihan agen senior dan dilanjutkan pada pelatihan unit manajer.

3. Penempatan $\longrightarrow$ memiliki peranan yang penting bagi pemasar untuk peningkatan produktivitas.

4. Kepuasan Kerja $\longrightarrow$ menyediakan sarana kerja yang lengkap, hubungan kerja, pembinaan oleh pemimpin unit dan system pertemuan.

5. Upah / Gaji $\longrightarrow$ diberikannya uang jalan, profisi, bonus produksi, tunjangan hari raya, jaminan kesehatan dsb.

Telkomsel membagi tiga tahap manajemen yaitu dengan perencanaan, pelaksanaan, dan monitoring evaluasi. Perencanaan yaitu harapan agar program berjalan dengan lancar, pelaksanaan yaitu usaha menjalankan program agar lancar, monitoring yaitu melihat sejauh mana keberhasilan produktivitas kerja.

Perbedaan penelitian diatas dengan penelitian yang disusun oleh Ahmad Yunadi penulis adalah penulis mengambil perusahaan jasa yaitu asuransi jiwa. Ini dipilih karena peneliti dapat secara langsung mengamati kegiatan manajemen yang dilakukan PT. Asuransi Jiwa Bumi Asih Jaya. Tujuan penelitian ini adalah bagaimana faktor rekruitment, pelatihan, tingkat 
kepuasan kerja serta kepemimpinan secara sendiri-sendiri maupun secara bersama-sama dapat menunjang tingkat produktivitas para pemasar Asuransi Jiwa Bumi Asih Jaya Distrik Demangan Cabang Jateng.

\section{H. Kerangka Pikir}

Kerangka pikir ini menjelaskan bahwa produktivitas sebagai pengukuran output berupa barang atau jasa dalam hubungannya dengan input yang berupa karyawan, modal, materi atau bahan baku dan peralatan. Produktivitas kerja menunjukkan bahwa individu merupakan perbandingan dari efektivitas keluaran (pencapaian unjuk kerja maksimal) dengan efisiensi salah satu masukan (tenaga kerja) yang mencangkup kuantitas, kualitas dalam waktu tertentu. Produktivitas kerja adalah suatu ukuran dari pada hasil kerja atau kinerja seseorang dengan proses input sebagai masukan dan output sebagai keluarannya yang merupakan hasil daripada kinerja karyawan dalam menentukan bagaimana usaha untuk mencapai produktivitas yang tinggi dalam suatu organisasi.

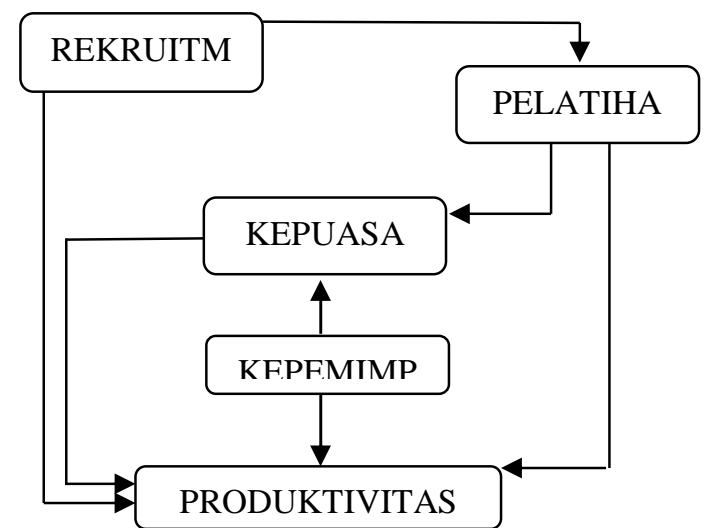

Gambar 2.1 Bagan Kerangka Pikir

Sebagai motor penggerak dari pada produktivitas ini adalah sumber daya manusia. Sumber daya manusia sebagai agent of change dalam proses perkembangan memerlukan suatu keterampilan dan pengetahuan sebagai pengembangan untuk menuju produktivitas yang tinggi. Karyawan yang merupakan bagian dari organisasi atau perusahaan perlu ditingkatkan produktivitasnya sebagai feed back dari perusahaan untuk tetap menjaga dan mengikat daripada karyawan agar tetap bergabung dalam perusahaan tersebut.

\section{METODE PENELITIAN}

\section{Pendekatan Penelitian}

Metode yang digunakan dalam penelitian ini adalah metode penelitian kualitatif. Metode kualitatif mempergunakan data yang dinyatakan secara verbal dan kualifikasinya bersifat teoritis. Data sebagai bukti dalam menguji kebenaran atau ketidakbenaran hipotesis, tidak

Study

Eksploratif

223 diolah melalui perhitungan mathematik dengan berbagai rumus statistika. Pengolahan data dilakukan secara rasional dengan mempergunakan pola berfikir tertentu menurut hukum logika.

\section{Lokasi Penelitian}


Penulis mengambil lokasi penelitian di PT. Asuransi Jiwa Bumi Asih Jaya Distrik Demangan Cabang Jateng. Bertempat di Jl. Ipda Tut Harsono Yogyakarta.

\section{Jenis Data Penelitian}

Jenis penelitian yang akan digunakan adalah penelitian eksploratif yang berusaha untuk mengembangkan konsep-konsep, menghimpun fakta. Usaha mendeskripsikan fakta-fakta itu pada tahap permulaan tertuju pada usaha mengemukakan gejala-gejala secara lengkap didalam aspek yang diselidiki agar jelas kondisi atau keadaannya, tetapi penelitian ini tidak dimaksudkan untuk pengujian hipotesis (anggapan sementara) berdasarkan teori-teori tertentu, melainkan untuk mengetahui sejauh mana tingkat produktivitas tenaga pemasar PT. Asuransi Jiwa Bumi Asih Jaya Distrik Demangan Cabang Jateng.

Metode eksploratif ini lebih menitikberatkan pada observasi dan suasana alamiah (naturalistis setting). Peneliti bertindak sebagai pengamat, yang hanya membuat kategori prilaku, mengamati gejala, dan mencatatnya dalam buku observasi. Penelitian ini menggunakan jenis penelitian kualitatif yang artinya menggunakan data yang disampaikan secara verbal dan klasifikasi bersifat teoritis, data yang diambil untuk menguji hipotesa tidak diolah melalui perhitungan matematis maupun dengan berbagai rumus statistik melainkan pengolahan data dilakukan secara rasional dengan berfikir menurut hukum dan logika (Moleong, 2004 : 06).

\section{Sumber Data Penelitian}

Sumber Data yang digunakan dalam penelitian ini adalah menggunakan dua sumber yaitu sumber yang didasarkan pada unsur manusia dan sumber yang didasarkan pada unsur non manusia.

\section{Teknik Pengumpulan Data}

a. Wawancara.

b. Observasi

c. Diskusi Kelompok

d. Studi Dokumentasi

\section{Teknik Analisa Data}

Analisis data adalah proses mencari dan menyusun secara sistematika data yang diperoleh dari hasil wawancara, catatan lapangan, dan bahan-bahan lain, sehingga dapat mudah dipamahi, dan temuannya dapat diinformasikan kepada orang lain (Sugiyono, 2009:231). Dalam penelitian ini peneliti akan menganalisis data dengan memakai model analisis Miles and Huberman. Adapun langkah-langkah analisis dalam penelitian ini adalah sebagai berikut:

a. Reduksi Data (Data Reduction)

b. Penyajian Data (Data Display)

c. Conclusion Drawing/Veryfication

\section{Waktu dan Tahapan Penelitan}

Penelitian ini menggunakan penelitian kualitatif dimana peneliti melakukan analisis pada saat pengumpulan data berlangsung dan setelah pengumpulan data yang akan dilakukan mulai tanggal 10 Agustus sampai tanggal 30 Agustus 2010. Peneliti disini menggunakan analisis data dimana apabila jawaban yang diwawancarai setelah dianalisis belum 
memuaskan, maka peneliti akan melanjutkan pertanyaan lagi sampai tahap tertentu sehingga nantinya diperoleh data yang dianggapnya kredibel. Tahapan analisis data yang dilakukan oleh peneliti ketika berada di lapangan dapat dilihat dari gambar di bawah ini:

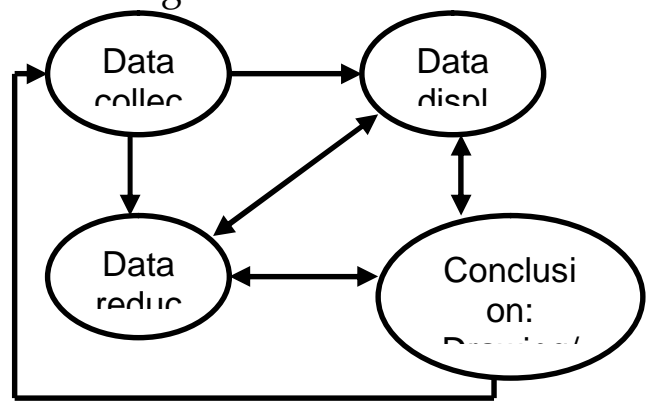

(Sumber: Prof. Dr. Sugiyono, 2009, Metode Penelitian Kuantitatif, Kualitatif dan R\&D)

\section{Gambar 3.1}

Komponen Dalam Analisis Data (Interactive model)

\section{J. HASIL PENELITIAN DAN PEMBAHASAN}

\section{Gambaran Umum}

\section{a. Sejarah Singkat PT. Asuransi Jiwa Bumi Asih Jaya}

PT. Asuransi Jiwa Bumi Asih Jaya, merupakan salah satu Perusahaan Asuransi Jiwa terbesar yang beroperasi di Indonesia, bahkan pada dekade tahun 80-an Perusahaan ini merupakan Perusahaan Asuransi terbesar ketiga setelah AJB Bumi Putra 1912, dan PN Jiwa Sraya. Perusahaan ini didirikan pada saat masa krisis ekonomi yang melanda Indonesia ditahun 1967-an. Bermula dari terdorongnya penghayatan yang mendalam terhadap tugas mulia Asuransi Jiwa yang ditekuni oleh putera Batak K.M Sinaga. Sejak tahun 1952, beliau yang semula bekerja sebagai pegawai AJB Bumi Putra 1912 terobsesi oleh cita-citanya mendirikan sebuah perusahaan Asuransi Jiwa yang terfokus pada pelayanan berdasarkan "Kasih Kepada Sesama". Cita-cita tersebut tidak langsung terwujud, walaupun beliau telah meninggalkan AJB Bumi Putra 1912.

\section{b. Visi, Misi dan Goal Perusahaan}

Sebagaimana halnya dengan Perusahaan besar maka perusahaan ini juga memiliki Pilosofi yang menjadi arah serta kebijaksanaan Perusahaan berupa Visi, Misi dan Goal. Adapun Visi, Misi dan Goal PT. Asuransi Jiwa Bumi Asih Jaya adalah sebagai berikut:

Visi Perusahaan : Agar setiap Warga Negara Indonesia memiliki Polis Asuransi Jiwa sebagai proteksi.

Misi Perusahaan : Mendidik orang agar mampu melihat jauh kedepan, mengajar orang untuk berhemat, dan

Study

Eksploratif

225 mengarakan orang untuk bergotong royong.

Goal Perusahaan : Untuk meningkatkan kesejahtraan hidap yang merata bagi rakyat Indonesia melalui produk asuransi

\section{c. Struktur Organisasi Perusahaan}

JURNAL EKONOMI SYARIAH INDONESIA, Volume II, No.2 Desember 2012 
PT. Asuransi Jiwa Bumi Asih Jaya mempunyai bagan struktur organisasi dari tingkat pusat sampai cabang, serta dari cabang sampai daerah (distrik):

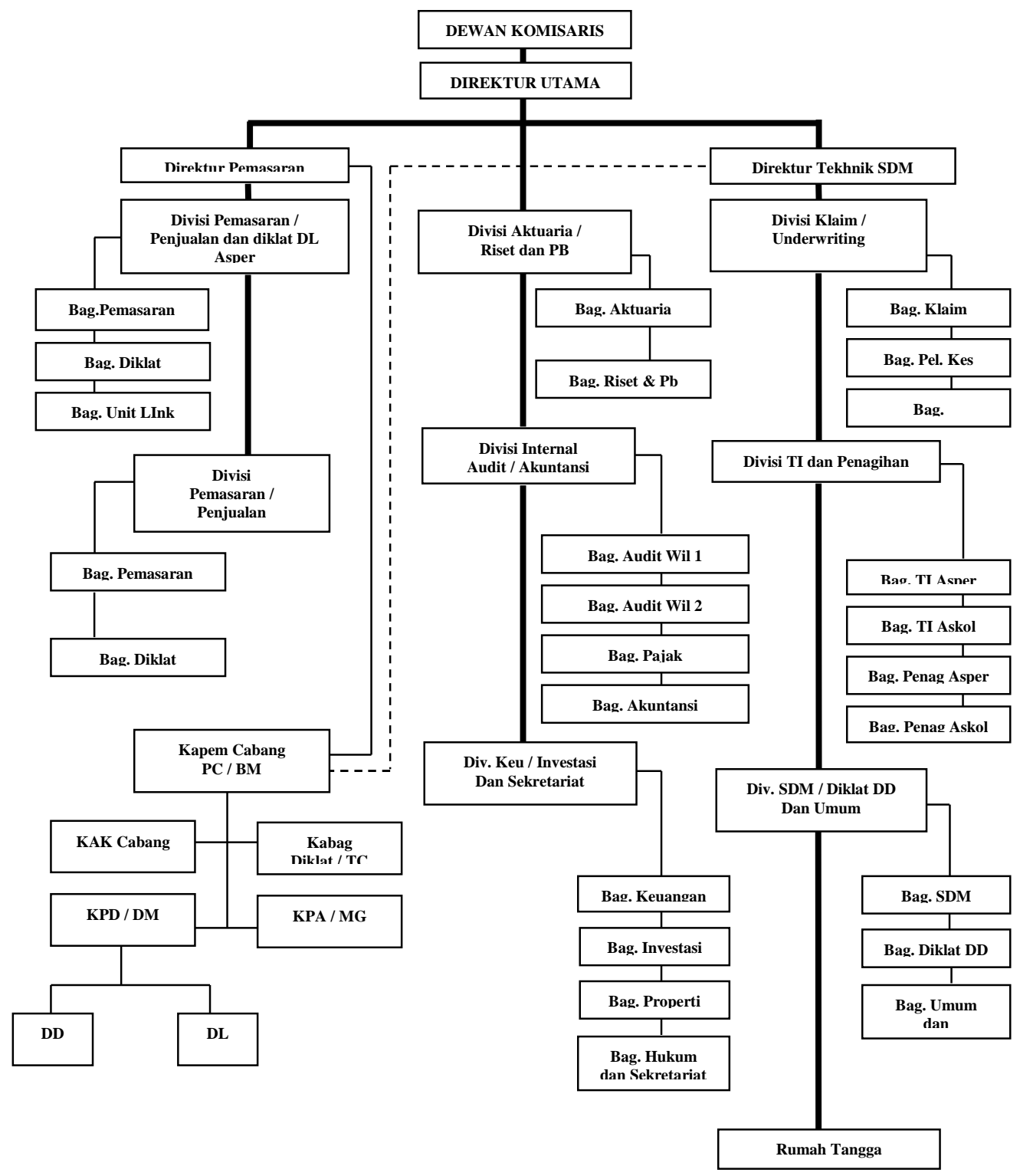

( Sumber : laporan tahunan / annual report 2005, Menjelang Masa 40

$$
\text { (1967 - 2007) }
$$

\section{Data Hasil Penelitian}

Dalam pengembangan sumber daya manusia berbasis kompetensi di PT Asuransi Jiwa Bumi Asih Jaya difokuskan pada bidang development, namun sejalan dengan perjalanan waktu sudah mulai ke aspek SDM lain seperti rekruitment, assessment development center dan performance management SDM secara keseluruhan. Kompetensi merupakan kemampuan yang didasari atas pengetahuan, keterampilan dan sikap kerja yang yang

Ahmad Yunadi 
dibutuhkan dalam memberikan layanan konsultasi dalam merencanakan, mengumpulkan data \& informasi, mengimplementasikan serta mengevaluasi program asuransi kepada nasabah. Program pengembangan kompetensi karyawan dilakukan melalui Individual Development Plan (IDP). Selain itu, PT Asuransi Jiwa Bumi Asih Jaya juga mengembangkan model competence master, yakni orang yang memiliki keahlian di bidang tertentu, yang diharapkan bisa menjadi contoh bagi orang lain. Dalam pelaksanaannya, pengukuran kompetensi pemasar dilakukan dengan cara masing-masing pemasar membuat Individual Performance Plan (IPP). Kompetensi yang harus diperlukan untuk menjadi agen pemasar memerlukan keterampilan pendukung yaitu:

- Presentation skills

- Negotiation skills

- Communication skills (oral, written, listening, body language)

- Business Law, (Labor, Contract, Government)

- General business knowledge

a. Produktivitas Agen Pemasar PT. Asuransi Jiwa Bumi Asih Jaya Distrik Demangan Cabang Jateng

Dari hasil wawancara yang dilakukan oleh peneliti ke salah seorang pegawai Dinas Dalam bagian pemasaran PT. Asuransi Jiwa Bumi Asih Jaya Distrik Demangan Cabang Jateng bernama Ibu Florida dapat diperoleh informasi bahwa produktivitas yang dihasilkan oleh agen pemasar PT. Asuransi Jiwa Bumi Asih Jaya Distrik Demangan Cabang Jateng sudah cukup baik dan maksimal. Ini dibuktikan dengan meningkatnya penjualan polis asuransi dari tahun ke tahun.

Tabel 4.1

Tabel Penjualan Polis Distrik Demangan

\begin{tabular}{|c|c|c|}
\hline Tahun & $\begin{array}{c}\text { Jumlah } \\
\text { Penjualan } \\
\text { Polis }\end{array}$ & $\begin{array}{c}\text { Jumlah } \\
\text { Portopolio }\end{array}$ \\
\hline 2005 & 570 & 2500 \\
2006 & 660 & 2800 \\
2007 & 690 & 3120 \\
2008 & 720 & 3600 \\
2009 & 735 & 3725 \\
\hline
\end{tabular}

Sumber : Laporan Tahunan (annual report) tahun 2010

Dari tabel di atas, dapat diketahui bahwa penjualan polis asuransi cenderung mengalami peningkatan 30 polis per tahun, tetapi pada tahun 2009 mengalami peningkatan yang kurang maksimal dibanding tahuntahun sebelumnya yaitu hanya 15 polis. Dengan penjualan polis yang meningkat dari tahun ke tahun, maka PT. Asuransi Jiwa Bumi Asih Jaya

Study

Eksploratif

227 mengalami pertumbuhan. Ini dibuktikannya dengan jumlah income premi yang masuk pada perusahaan. Muntiyah menuturkan bahwa: "Jumlah premi yang terdiri atas premi yang baru masuk ataupun premi lanjutan selalu mengalami kemajuan“. (wawancara tanggal 20 Agustus 2010) 
Tabel 4.2

Tabel Pertumbuhan Income Distrik Demangan selama 5 Tahun

\begin{tabular}{|c|c|c|c|}
\hline Tahun & UPP & PL & Jumlah \\
\hline 2005 & 430.000 .000 & 1.940 .000 .000 & 2.370 .000 .000 \\
2006 & 440.000 .000 & 2.120 .400 .000 & 2.560 .400 .000 \\
2007 & 620.000 .000 & 2.160 .060 .000 & 2.780 .060 .000 \\
2008 & 682.000 .000 & 2.288 .300 .000 & 2.886 .300 .000 \\
2009 & 690.000 .000 & 2.430 .000 .000 & 3.120 .000 .000 \\
\hline
\end{tabular}

Sumber : Laporan Tahunan (annual report) tahun 2010

Keterangan :

(Dalam rupiah)

UPP : Uang Premi Pertama

PL : Premi Lanjutan

Gambar 4.4

Grafik Pertumbuhan Income Distrik Demangan selama 5 Tahun

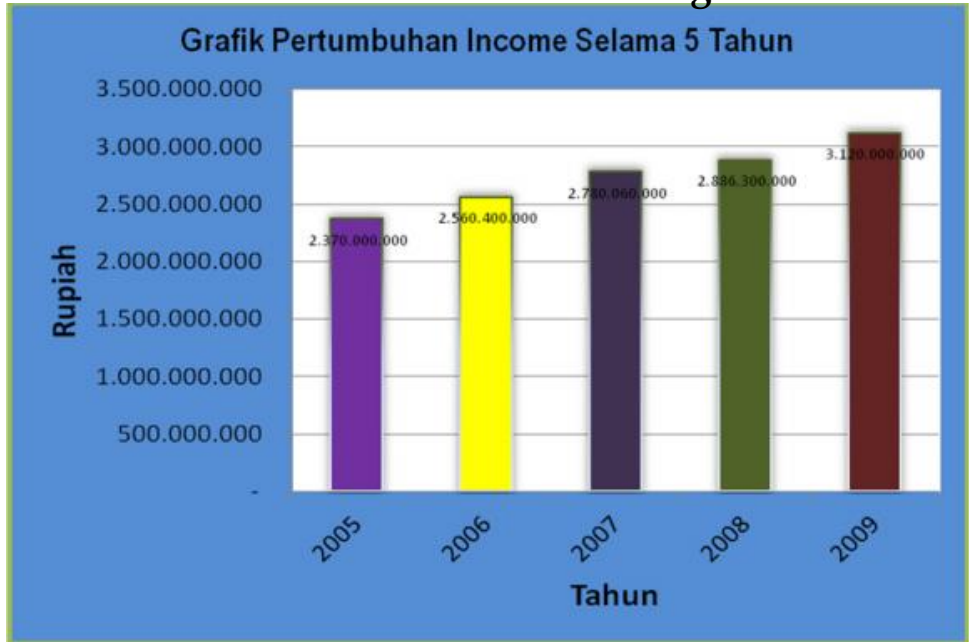

Sumber : Sumber : Laporan Tahunan (annual report) tahun 2010

Dilihat dari grafik di atas menunjukan peningkatan pendapatan dari premi yang masuk. Hal ini membuktikan bahwa Bumi Asih Jaya Distrik Demangan merupakan salah satu kantor Distrik yang sehat dan mampu bersaing ditengah-tengah persaingan perusahaan asuransi yang semakin berkembang. Selain itu ditunjukkan juga dengan Distrik Demangan menduduki peringkat paling atas diantara distrik-distrik lainnya seluruh Jawa Tengah.

Tabel 4.3

Tabel Pertumbuhan Income Seluruh Distrik se-Jateng selama 5

Tahun

\begin{tabular}{|c|c|c|c|c|c|c|c|}
\hline \multirow{3}{*}{$\begin{array}{l}\text { No } \\
1\end{array}$} & \multirow{3}{*}{$\mathrm{Kancm}$} & \multicolumn{5}{|c|}{ Pondapatan Promi } & \multirow{3}{*}{$\mathrm{P}$} \\
\hline & & 2005 & 2000 & 2007 & 2008 & 2009 & \\
\hline & & 2370 & 25604 & 2780 & 28863 & 3120 & \\
\hline 2 & Kauman & 1563 & 1721 & 1930 & 2335 & 2500 & 49 \\
\hline 3 & Slenrta 1 & 1162 & 1630 & 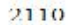 & 2320 & 2110 & 11 \\
\hline 4 & Madium & 1534 & 1820 & 2105 & 2210 & 2320 & 37 \\
\hline 3 & Purvoukertu & 1121 & $1 \$ 10$ & 1835 & 2150 & 2210 & 31 \\
\hline 6 & S k karta 2 & 731 & 220 & 1211 & 1500 & 1020 & 37 \\
\hline 7 & Flatert & 1873 & 2150 & 2213 & 2510 & 2432 & 78 \\
\hline 8 & Cilacan & 1472 & 1635 & 1820 & 2010 & 2430 & 43 \\
\hline 9 & Ngawi & 230 & 495 & 720 & 812 & 1250 & 55 \\
\hline 10 & c $\mathrm{i}$ mada & 16,3 & $18 \% 4$ & 23,0 & 2,12 & $3 \%, 0$ & $1 \times 6$ \\
\hline 11 & Ponorogo & 1526 & 1821 & 2150 & 2340 & 2600 & 47 \\
\hline 12. & MCF-1 & 863 & 220 & 1320 & 1425 & 1800 & 110 \\
\hline 13 & KPA 2 & 596 & 750 & 832 & 1201 & 1583 & 172 \\
\hline 11 & $\mathrm{MC}+4$ & $1 \times 1$ & 320 & $\$ 11$ & $x, 0$ & $13 \%$ & 210 \\
\hline & Cabang & 17484 & 20075.4 & 23887 & 27061 & 30647 & 62 \\
\hline
\end{tabular}

Ahmad

Yunadi 
Sumber : Laporan Tahunan (annual report) tahun 2010

Keterangan :

(Dalam jutaan rupiah)

P : Pertumbuhan polis rata-rata per tahun

Dapat dilihat pada tabel di atas bahwa Distrik Demangan menduduki peringkat paling atas diantara distrik-distrik lain seluruh cabang Jawa Tengah (Jateng), hal ini disebabkan adanya pembagian fungsi audit internal, penyempurnaan tugas di masing-masing divisi yang berpengaruh terhadap efektifitas dalam hal pelayanan dan juga dalam mengolah pekerjaan yang ada di Bumi Asih Jaya Distrik Demangan sendiri sehingga produktivitasnya pun cukup baik. Selain itu adanya Sumber Daya Manusia (SDM) yang berkualitas mampu menunjang layanan baik terhadap nasabah maupun penjualan polis-polis yang ada. Dalam mengelola para pemasarnya agar dapat meningkatkan kinerja, pemimpin distrik Demangan Cabang Jateng memiliki cara yang efektif yaitu:

a. Adanya Goal atau Tujuan yang Jelas

b. Score keeping / pencatatan angka

c. Adanya Feedback / Laporan dari Aktivitas

d. Membiasakan karakter Pemenang kepada pemasar

Dengan empat cara yang dilakukan pimpinan tersebut di atas diantaranya Adanya goal atau penetapan tujuan, score keeping atau pencatatan angka, feedback atau Laporan dari aktivitas dan membiasakan karakter pemenang pada diri pemasar, maka akan semakin mendukung terciptanya suasana yang mendukung pengoptimalan produktivitas agen pemasar sehingga bisa membantu peningkatan penjualan polis asuransi, dengan demikian berpengaruh juga terhadap income premi perusahaan.

Seperti apa yang telah dikatakan oleh Muntiyah mengenai aktivitas penjualan oleh pemasar, dalam menjalankan aktivitasnya didasarkan oleh standar perusahaan yang sesuai dengan keputusan Direksi No.61/KEP/DIR/2006 tentang standar penilaian kinerja pejabat dan tenaga produksi kantor pemasaran, dimana di dalamnya mencakup:
a. Penilaian pretasi karyawan
b. Employe Rating
c. Performance Appraisal
d. Employe Evaluation
e. Personal Review
f. Behaviour Assasmen

\section{b. Rekruitment dan Seleksi}

Didalam upaya untuk mendapatkan Sumberdaya Manusia dalam hal ini untuk para Pemasar baik dalam jumlah maupun kualitas maka dilakukan Rekruitment dan Seleksi.

\footnotetext{
Study

Eksploratif
} 
Tabel 4.4

Tabel Data Peserta Seleksi 3 Tahun Terakhir

\begin{tabular}{|c|c|c|c|}
\hline Tahun & Periods & Junzlah pelamar & Jumlah yang lolos \\
\hline \multirow{4}{*}{2008} & Januari & 12 & 3 \\
\hline & April & 22 & 3 \\
\hline & July & 20 & 3 \\
\hline & Okluther & 34 & 3 \\
\hline \multirow{4}{*}{2009} & Januari & 10 & 3 \\
\hline & April & 11 & 3 \\
\hline & July & 8 & 3 \\
\hline & Oksculuer & 20 & 3 \\
\hline \multirow{3}{*}{2010} & Januari & 15 & 3 \\
\hline & July & 23 & 3 \\
\hline & Ostober: & 20 & 3 \\
\hline
\end{tabular}

Sumber : Dokumentasi PT. Asuransi Jiwa Bumi Asih Jaya (2010)

Dalam proses rekruitment menurut data yang ada bahwa PT. Asuransi Jiwa Bumi Asih Jaya Distrik Demangan Cabang Jateng melakukan seleksi penerimaan karyawan untuk menjadi agen pemasar empat kali dalam satu tahun, itu dilakukan karena pelamar yang mendaftar sebagai agen asuransi sedikit sehingga rekruitment sering dilakukan, mengingat dari pelamar-pelamar tersebut hanya tiga pelamar saja yang nantinya masuk dan bergabung dengan bahwa PT. Asuransi Jiwa Bumi Asih Jaya Distrik Demangan Cabang Jateng dalam satu periode.

Para pelamar diseleksi sesuai spesifikasi jabatan maupun kualifikasi jabatan untuk mendapatkan karakteristik individu mulai dari tinjauan psikologis seperti: kecerdasan (Inteligent), kepribadian (personality), bakat (attitude), minat (interest), prestasi (echievement), tinjauan pengetahuan (knowledge), tinjauan penampilan fisik (Performance). Muntiyah selaku Distrik Manager mengatakan bahwa rekrutment sendiri menerapkan penyeleksian yang berbasis kompetensi dengan melibatkan pihak ketiga seperti psikolog dan konsultan yang ahli di bidang assessment penerimaan karyawan.

\section{c. Pelatihan}

Para pemasar asuransi jiwa berasal dari berbagai bidang kesarjanaan (S1 hingga S2), antara lain bidang Hukum, Ekonomi, Bisnis, Peternakan, Sastra, dan Kedokteran, tetapi itu semua tidak begitu masalah karena kualitas kompensasi finansial yang mereka dapatkan terlihat dari penampilan dan kesejahteraan hidup yang mereka nikmati saat ini, namun semua itu bergantung pada kinerja yang mereka hasilkan. Secara hakiki, suatu pekerjaan disebut sebagai profesi bila memenuhi beberapa kriteria, yakni:

a. Ada kompetensi dan keterampilan tertentu pada setiap orang yang bergelut di dalamnya.

b. Memiliki Kode Etik.

c. Masyarakat mengakui dan membutuhkan profesi tersebut.

Tahap training ini dilakukan untuk mengetahui apakah orang tersebut memenuhi kriteria sebagai seorang agen sehingga dapat melakukan kegiatan penawaran dengan baik. Sebelum melakukan pekerjaannya untuk menawarkan produk Asuransi, agen pemasar selalu dibekali dengan segala sesuatu mengenai produk dari perusahaan itu sendiri. Hal ini dilakukan agar agen pemasar menguasai produk dan dapat menjawab semua pertanyaan dari nasabah mengenai produk Asuransi.

Ahmad Yunadi Mengingat seorang pemasar adalah ujung tombak dari perusahaan 
asuransi serta selalu berhadapan langsung dengan calon pembeli produk yaitu calon nasabah.

Selain pendidikan dan pelatihan (training) yang ditujukan untuk seseorang yang ingin menjadi agen pemasar, ada juga retraining yaitu pendidikan dan pelatihan untuk meningkatkan kualitas SDM Bumi Asih Jaya. Pelatihan yang dilakukan telah disesuaikan dengan kurikulum dan materinya selalu baru/up to date yang didasarkan oleh Asosiasi Perasuransian se-Indonesia. Kurikulum untuk retraining berbeda dengan pada saat pelatihan/training.

\section{d. Kepuasan Kerja}

PT. Asuransi Jiwa Bumi Asih Jaya Distrik Demangan Cabang Jateng dalam mengembangkan agen pemasarnya dan sejalan dengan visi PT. Asuransi Jiwa Bumi Asih Jaya yaitu "Agar setiap Warga Negara Indonesia memiliki Polis Asuransi Jiwa sebagai proteksi" tetap berusaha semaksimal mungkin memberikan perasaan senang dan berupaya agar para pemasar tetap berada diperusahaan. Selain itu adanya sarana dan prasarana yang lengkap menjadi salah satu kepuasan kerja bagi seorang pemasar.

Mengenai upah yang diberikan PT. Asuransi Jiwa Bumi Asih Jaya Distrik Demangan Cabang Jateng ditemukan dalam dua bentuk yaitu bonus produksi yang diterimakan setiap bulan dan profisi. Pengupahan terakhir diatur dengan prinsip-prinsip sebagai berikut:

a. Tidak ada perbedaan penerimaan bonus produksi bulanan baik wanita maupun laki-laki, yang belum kawin atau telah kawin dan menurut umurnya.

b. Pemberian bonus produksi bulanan disesuaikan dengan luasnya tugas pekerjaan, pencapaian UPP (Uang Pertanggungan Pertama), income yang diperoleh serta aktivitas yang bersangkutan.

c. Bonus produksi bulanan diberikan atas dasar jabatan yang dipangku dengan memperhatikan masa kerja pemasar yang bersangkutan.

Jadi sistem pengupahan yang ada didasarkan atas aktivitas para pemasar itu sendiri, sehingga tidak adanya batasan atas penghasilan yang diperoleh, serta antara pemasar satu dengan pemasar yang lainnya mendapatkan upah yang berbeda-beda sesuai dengan usahanya yaitu untuk menjual produk asuransi jiwa. Disamping itu, pemasar juga diberikan penghasilan-penghasilan lain yang tidak dapat dilepaskan dengan bonus produksi bulanan. Dalam arti pemberiannya melekat dengan bonus produksi bulanan yaitu profisi. Besarnya profisi yang diterima sama halnya dengan bonus produksi yang diterima tiap bulan tetapi ini diterimakan setelah adanya kesepakatan antara calon nasabah dengan perusahaan. Besarnya profisi adalah:

Study

Eksploratif

231
2\% X Masa Bayar Premi X UPP

Jadi besarnya profisi adalah $2 \%$ dari masa bayar premi dikalikan uang premi pertama yang dibayarkan oleh nasabah. Semakin lama masa 
bayar premi ataupun semakin besar uang premi pertama yang dibayarkan oleh nasabah maka pemasar mendapatkan profisi yang besar juga.

\section{e. Kepemimpinan}

Kepemimpinan seorang manajer akan mampu membedakan karakteristik suatu organisasi dengan organisasi lain. Kepemimpinan yang dinamis dan efektif merupakan sumber daya yang paling pokok yang sulit dijumpai, oleh karena itu setiap pemimpin harus memahami teori kepemimpinan dengan mengetahui bakat atau potensi yang dimiliki oleh para bawahannya ataupun yang dimiliki oleh dirinya sendiri.

Pemimpin yang baik adalah seorang pemimpin yang mampu membangkitkan semangat kerja dan menanamkan rasa percaya diri serta tanggung jawab pada bawahan untuk melaksanakan tugas-tugas penuh tanggung jawab guna mencapai produktivitas perusahaan. Hal ini adanya tuntutan organisasi bahwa pemimpin dapat memprioritaskan kepemimpinannya yang berorientasi pada tugas dan hubungan antar manusia yang bertujuan untuk meningkatkan kematangan bawahan. Menurut para agen pemasar, pimpinan yang mereka harapkan adalah seorang pemimpin yang dapat juga merasakan apa yang pemasar rasakan. Dapat memecahkan permasalahan agen pemasarnya, sesuai dengan yang diungkapkan oleh beberapa agen pemasar di bawah ini:

\section{K. PEMBAHASAN}

Pembahasan ini akan menjelaskan mengenai tingkat produktivitas agen pemasar PT. Asuransi Jiwa Bumi Asih Jaya Distrik Demangan Cabang Jateng dengan memperhatikan faktor-faktor yang terkait didalamnya. Sebagai motor penggerak produktivitas ini adalah sumber daya manusia. Sumber daya manusia sebagai agent of change dalam proses perkembangan memerlukan suatu keterampilan dan pengetahuan sebagai pengembangan untuk menuju produktivitas yang tinggi. Faktor yang menunjang produktivitas agen pemasar PT. Asuransi Jiwa Bumi Asih Jaya Distrik Demangan Cabang Jateng adalah:

\section{Produktivitas}

Tingkat produktivitas PT. Asuransi Jiwa Bumi Asih Jaya Distrik Demangan Cabang Jateng sudah cukup baik, ini didasarkan oleh penjualan polis asuransi yang tiap tahunnya meningkat dan sudah sesuai dengan standar yang dietapkan oleh perusahaan. Bila dibandingkan dengan distrik-distrik lain dalam satu cabang yaitu cabang Jateng, Distrik Demangan selalu menduduki peringkat pertama (Lihat Tabel 4.3), itu dikarenakan penjualan polis yang besar serta meningkatnya income setiap tahunnya. Semua itu tidak lepas dari adanya Sumber Daya Manusia (SDM) dalam hal ini adalah para agen pemasar yang berkualitas mampu menunjang layanan baik terhadap nasabah maupun penjualan polis-polis yang ada. Semakin banyak polis terjual maka semakin meningkatnya produktivitas agen pemasar. Untuk itu perusahaan harus lebih dapat mengelola sumbrdaya manusianya dalam hal ini adalah agen pemasar yang menjadi ujung tombak bagi perusahaan asuransi.

Dalam mengelola para pemasarnya agar dapat meningkatkan kinerja, pemimpin distrik Demangan Cabang Jateng memiliki empat cara

Ahmad

Yunadi yang efektif. Penetapan tujuan yang dilakukan oleh para pemasar sendiri merupakan suatu tanggungjawab penuh atas hasil yang diperoleh agar 
tidak adanya beban yang dirasakan dalam diri pemasar. Selain itu pencatatan indeks prestasi pribadi, sejarah prestasi, dan standar prestasi yang diinginkan agen pemasar agar aktivitasnya bisa lebih terpantau dengan baik, meningkatkan Laporan dari aktivitas yang dilakukan oleh pemasar agar kegiatan pemasar akan lebih terkontrol dan terkendali dengan baik oleh pimpinan serta yang lebih penting adalah membiasakan pemasar memiliki karakter pemenang. Cara ini melatih agar pemasar berani dan bertanggung jawab atas pekerjaannya.

2. Rekruitment dan Seleksi

PT. Asuransi Jiwa Bumi Asih Jaya Distrik Demangan Cabang Jateng melakukan rekruitment atau seleksi dengan cara menerapkan penyeleksian yang berbasis kompetensi dengan melibatkan pihak ketiga seperti psikolog dan konsultan yang ahli di bidang assessment penerimaan karyawan, hanya saja sedikit mengalami hambatan yaitu biaya yang diperlukan tidak sedikit. Proses Rekruitment yang dilakukan oleh PT. Asuransi Jiwa Bumi Asih Jaya Distrik Demangan Cabang Jateng menggunakan beberapa metode yaitu dengan personal kontak, melalui surat kabar, pusat pengaruh, pemegang polis, Universitas, Depnaker, Lembaga tenaga kerja, surat lansung dan dengan cara agen mencari agen. Macam tes yang dilakukan selain menggunakan tes tulis, PT. Asuransi Jiwa Bumi Asih Jaya Distrik Demangan Cabang Jateng menggunakan tes wawancara serta tes psikologi untuk mendapatkan pelamar yang mempunyai karakteristik individu sesuai dengan pekerjaannya yaitu yaitu minatnya sangat besar terhadap pekerjaan menjual, bakat, kecerdasan, pengetahuan yang luas serta cara komunikasi pada orang lain. Selain itu juga pantang menyerah, gigih dan mempunyai karakter pemimpin.

PT. Asuransi Jiwa Bumi Asih Jaya Distrik Demangan Cabang Jateng melakukan seleksi penerimaan karyawan untuk menjadi agen pemasar empat kali dalam satu tahun, itu dilakukan karena prosentase pelamar yang mendaftar sebagai agen asuransi sedikit sehingga rekruitment sering dilakukan, mengingat dari pelamar-pelamar tersebut hanya tiga pelamar saja yang nantinya masuk dan bergabung dengan PT. Asuransi Jiwa Bumi Asih Jaya Distrik Demangan Cabang Jateng dalam satu periode. Sehingga dalam satu tahun PT. Asuransi Jiwa Bumi Asih Jaya Distrik Demangan Cabang Jateng ini hanya menerima 12 orang pemasar saja.

3. Pelatihan

PT. Asuransi Jiwa Bumi Asih Jaya Distrik Demangan Cabang Jateng menyelenggarakan pelatihan untuk agen pemasar mulai dan tingkat dasar (Basic) yaitu Pelatihan masa orientasi (PAMO) yang diselenggarakan oleh Kepala Pernasaran Distrik dengan materi mengenai pengenalan perusahaan dan produk-produk asuransi, Peatihan Agen (PAG)

Study

Eksploratif

233 diselenggarakan di Cabang dengan materi cara bagaimana teknik bernegosiasi dan cara menghadapi nasabah yang mempunyai karakter berbeda-beda, Pelatihan Agen Senior (PAS) dengan materi penguasaan internet serta membahas bagaimana cara menjual produk asuransi dengan media internet, dan yang terakhir Pelatihan Unit Manajer (PUM) di Training centre dengan materi untuk pendalaman dari materi-materi dan

JURNAL EKONOMI SYARIAH INDONESIA, Volume II, No.2 Desember 2012 
kurikulum yang sudah ada, sernu7a dilakukan perusahaan dalam rangka meningkatkan keterampilan para agen pemasar. Serta agar pemasar dapat mengetahui bagaimana cara agar nasabah mau membeli produk asuransi yang ditawarkan dan berkarakter pemenang.

Pelatihan atau Training dilakukan oleh perusahaan setiap 3 bulan sekali selama satu minggu untuk mendapatkan Sumber Daya Manusia (SDM) yang handal. Materi yang disampaikan pada trainning agen pemasar baru adalah materi mengenai perusahaan asuransi pada umumnya serta PT. Asuransi Jiwa Bumi Asih Jaya khususnya, adapula materi lain mengenai pengembangan dan cara membentuk sifat percaya diri, mengingat perusahaan sangat membutuhkan agen pemasar yang mempunyai rasa percaya diri yang besar. Selain pendidikan dan pelatihan (training) yang ditujukan untuk seseorang yang ingin menjadi agen pemasar, ada juga retraining yaitu pendidikan dan pelatihan untuk meningkatkan kualitas SDM Bumi Asih Jaya. Pelatihan yang dilakukan telah diesuaikan dengan kurikulum dan materinya selalu baru / up to date. Seperti yang baru-baru ini yaitu pelatihan agen senior yang dilaksanakan bulan agustus dengan materi penguasaan penggunaan sarana internet sebagai media penjualan itu sangat dirasakan dampaknya oleh pemasar karena menunjang tingkat produktivitas dimana pemasar dapat melakukan penjualan jarak jauh menggunakan sarana yang lebih mudah dan efisien. Efisien waktu serta efisien dalam hal biaya.

\section{Kepuasan Kerja}

PT. Asuransi Jiwa Bumi Asih Jaya Distrik Demangan Cabang Jateng dalam hal ini berusaha memberikan yang terbaik bagi anggota organisasi yang terbaik. Searah perjalanannya para pemasar yang merupakan ujung tombak dari perusahaan asuransi perlu ditingkatkan produktivitasnya. Timbal balik dari perusahaan untuk tetap menjaga dan mengikat pemasar agar tetap bergabung dalam perusahaan. Kepuasan kerja bagi seorang agen pemasar akan berdampak positif bagi perusahaan, yang tentunya meningkatkan produktivitas perusahaan tersebut. Kebersamaan dan loyalitas antar sesama pemasar juga sangat menunjang tingkat produktivitas dimana antar sesama pemasar tidak ada selisih paham sehingga lingkungan kerja menjadi sehat, aman dan nyaman.

Begitupun juga memberikan imbalan kerja, PT. Asuransi Jiwa Bumi Asih Jaya Distrik Demangan Cabang Jateng ditemukan dalam dua bentuk yaitu bonus produksi yang diterimakan setiap bulan dan profisi. Profisi ini yang sangat menentukan tingkat produktivitas kerja karena dengan mendapatkan profisi yang besar, maka pemasar mendapatkan kepuasan atas pekerjaan yang dilakukan, sehingga pemasar lebih terpacu untuk meningkatkan produktivitas kerjanya. Untuk mendapatkan profisi yang besar itu dipengaruhi oleh 3 hal yaitu Jumlah polis, lamanya masa bayar premi dan besarnya uang premi pertama, jadi semakin lama masa bayar premi atau semakin besar premi pertama yang dibayarkan oleh nasabah maka pemasar mendapatkan profisi yang besar dan akhirnya menimbulkan kepuasan kerja. Contohnya: seorang pemasar berhasil closing dengan seorang nasabah dengan masa bayar premi 9 tahun dan uang premi pertama Rp.925.000,-. Maka pemasar tersebut akan mendapatkan profisi sebesar 2\% XMBPXUPP = Rp.166.500,-

\section{Ahmad \\ Yunadi}


Selain memperoleh imbalan dalam bentuk kompensasi, pemasar berprestasi diberikan berbagai insentif baik sebagai individu maupun kelompok. Hal ini dengan diberikannya tunjangan-tunjangan yang relatif tinggi bagi pemasarnya. Seperti tunjangan bagi para agen pemasar yang bekerja di lapangan, misalnya tunjangan transportasi, kesehatan dan keamanan dalam bekerja. Hal ini dirasakan pemasar cukup memberikan semangat dalam bekerja dan sebagai motivasi untuk lebih giat bekerja. Selain itu perusahaan memberikan penghargaan, antara lain serta penghasilan yang lebih dari cukup (jauh di atas rata-rata), berbagai pelatihan di dalam maupun di luar negeri, serta bentuk penghargaan lain seperti memberikan apresiasi bagi agen pemasar berprestasi melalui ajang Top Agen Award tiap tahunnya yang diselenggarakan oleh Asosiasi Perasuransian se-Indonesia.

\section{Kepemimpinan}

Kepemimpinan seorang manajer akan mampu membedakan karakteristik suatu organisasi dengan organisasi lain. Kepemimpinan yang dinamis dan efektif merupakan sumber daya yang paling pokok yang sulit dijumpai, oleh karena itu setiap pemimpin harus memahami teori kepemimpinan dengan mengetahui bakat atau potensi yang dimiliki oleh para bawahannya ataupun yang dimiliki oleh dirinya sendiri. Hasil dari penelitian serta wawancara dengan agen pemasar, penulis mencoba menganalisa sifat-sifat pimpinan dalam melaksanakan tugasnya seharihari. Sifat-sifat yang penulis peroleh dari hasil wawancara langsung adalah sebagai berikut:

a. Dalam menjalin hubungan dengan para agen pemasar, pimpinan mempunyai hubungan yang baik.

b. Pimpinan selalu memberikan keterangan yang jelas dalam memberikan tugas kepada para pemasar.

c. Dalam mengawasi pemasar, pimpinan memberikan keleluasaan kepada para pemasar tetapi tetap mengawasi dengan ketat.

d. Apabila terdapat pemasar yang sakit, pimpinan menganjurkan untuk beristirahat/berobat.

e. Pimpinan sering terlihat membantu langsung kesulitan para pemasar dalam menjalankan aktivitas penjualannya selama di lapangan.

f. Bagi pimpinan, tugas merupakan prioritas utama, karena hal ini menyangkut pemenuhan target dan merupakan tanggungjawabnya, tetapi pimpinan mengerti betul bahwa kerjasama dengan para pemasar merupakan faktor terpenting untuk mencapai tujuan suatu perusahaan, dari faktor tersebut beliau memandang bahwa kesejahteraan para bawahannya harus betul-betul diperhatikan.

Study

Eksploratif

235
Dari sifat-sifat yang ada di atas maka dapat dikatakan bahwa kepemimpinan yang ada pada PT. Asuransi Jiwa Bumi Asih Jaya Distrik Demangan Cabang Jateng merupakan pola kepemimpinan informal. Dimana kepemimpinan informal merupakan seni kemampuan mempengaruhi perilaku manusia dan kemampuan untuk mengendalikan

JURNAL EKONOMI SYARIAH INDONESIA, Volume II, No.2 Desember 2012 
orang orang dalam organisasi agar perilaku mereka sesuai dengan perilaku yang di inginkan oleh pimpinan tanpa adanya perintah tertulis ataupun dalam bentuk formal. Jadi kepemimpinan informal mengalir dengan sendirinya. Efektivitas kepemimpinan informal terlihat pada pengakuan nyata dan penerimaan dalam praktek atas kepemimpinan seseorang. Biasanya kepemimpinan informal didasarkan pada beberapa kriteria diantaranya adalah sebagai berikut :

1. Kemampuan memikat hati orang lain.

2. Kemampuan dalam membina hubungan yang serasi dengan orang lain.

3. Penguasaan atas makna tujuan organisasi yang hendak dicapai.

4. Penguasaan tentang implikasi-implikasi pencapaian dalam kegiatan-kegiatan operasional.

5. Pemilihan atas keahlian tertentu yang tidak dimiliki oleh orang lain.

L. PENUTUP

\section{Kesimpulan}

Berdasarkan hasil penelitian, penulis dapat mengambil kesimpulan bahwa:

1. Secara keseluruhan faktor mulai dari Rekruitment/seleksi, Pelatihan, Kepuasan kerja dan Kepemimpinan dapat menunjang keberhasilan perusahaan dengan tingkat produktifitas yang cukup baik. Ini dibuktikannya penjualan polis yang tiap tahun relatif meningkat (data statistik perusahaan) ini cukup menggambarkan kesuksesan bagi perusahaan. PT. Asuransi Jiwa Bumi Asih Jaya Distrik Demangan Cabang Jateng melakukan rekruitment untuk mencari agen pemasar yang sesuai dengan pekerjaan dengan melibatkan psikolog untuk mendapatkan karakter individu diantaranya minatnya sangat besar terhadap pekerjaan menjual, bakat, kecerdasan, pengetahuan yang luas serta cara komunikasi pada orang lain, pantang menyerah, gigih dan mempunyai karakter pemimpin. Kemudian diselenggarakannya pelatihan untuk agen pemasar mulai dan tingkat dasar (Basic) yaitu Pelatihan masa orientasi (PAMO) yang diselenggarakan oleh Kepala Pernasaran Distrik dengan materi mengenai pengenalan perusahaan dan produk-produk asuransi, Peatihan Agen (PAG) diselenggarakan di Cabang dengan materi cara bagaimana teknik bernegosiasi dan cara menghadapi nasabah yang mempunyai karakter berbeda-beda, Pelatihan Agen Senior (PAS) dengan materi penguasaan internet serta membahas bagaimana cara menjual produk asuransi dengan media internet, dan yang terakhir Pelatihan Unit Manajer (PUM) di Training centre dengan materi untuk pendalaman dari materi-materi dan kurikulum yang sudah ada. Dan setiap pelatihan pimpinan selalu memberikan materi mengenai membiasakan karakter pemimpin pada diri pemasar. Kepuasan kerja juga tampak pada pemasar manakala hubungan yang erat antara pimpinan dan pemasar, serta antara sesama pemasar, seain itu pemberian profisi yang sesuai dengan produktivitas dalam bekerja. Dengan tingginya

Ahmad Yunadi tingkat produktivitas, maka besar juga profisi yang diperoleh sehingga menimbulkan kepuasan bagi pemasar itu sendiri. Selain itu 
kepemimpinan yang dilakukan PT. Asuransi Jiwa Bumi Asih Jaya Distrik Demangan Cabang Jateng sudah sangat baik dimana pemasar memberikan apresiasi terhadap pimpinannya serta bersemangat dalam bekerja.

2. Dalam penelitian ini ditemukan hal yang sangat spesifik, yaitu untuk menjadi seorang agen pemasar itu dibutuhkan karakteristik individu yang khusus bila dibandingkan dengan pekerjaan lainnya yaitu harus memiliki "Karakter Pemenang". Dimana seorang agen pemasar mempunyai karakter berani dan sehingga selalu bertanggung jawab atas pekerjaannya.

\section{Saran}

Berdasarkan hasil penelitian dan analisis yang telah dilakukan, maka penulis mencoba memberikan masukan atau saran yang nantinya dapat dijadikan referensi bagi perkembangan PT. Asuransi Jiwa Bumi Asih Jaya Distrik Demangan Cabang Jateng maupun bagi penulis selanjutnya yang akan mengambil penelitian dengan konsep yang sama, adapun saran tersebut antara lain :

1. Bagi perusahaan.

a. Berdasarkan analisis dalam penelitian menujukkan bahwa Rekruitment/seleksi, Pelatihan, Kepuasa kerja dan Kepemimpinan dapat menunjang produktivitas agen pemasar. Oleh sebab itu pihak perusahaan perlu menggunakan proses rekruitment yang didasarkan oleh karakteristik individu untuk proses seleksi berikutnya, serta pelatihan tetap memberikan materi mengenai karakter pemenang. Profisi tetap digunakan sebagai acuan pemasar meningkatkan produktivitasnya agar memperoleh kepuasan dan yang terakhir kepemimpinan yang sudah baik perlu ditingkatkan lagi.

b. Peningkatan hubungan antar pemasar perlu dilakukan dengan tetap menjaga hubungan yang baik antar pemasar yang diupayakan dari pihak perusahaan dalam memberikan nuansa keharmonisan dalam perusahaan sehingga antar pemasar merasa saling membutuhkan satu dengan yang lainnya.

c. Adanya peran pimpinan dalam ikut serta berpartisipasi memberikan masukan-masukan dan solusi atas permasalahan di lapangan yang dihadapi oleh pemasar serta menjalin kedekatan agar nantinya pemasar merasa dirinya dihargai.

2. Bagi peneliti selanjutnya

Peneliti selanjutnya diharapkan dapat meneliti faktor-faktor lain yang berhubungan dengan masalah produktivtas kerja, seperti motivasi kerja, disiplin kerja maupun kondisi fisik lingkungan

Study

Eksploratif

237 kerja. Hal ini dikarenakan dalam penelitian ini data produktivitas kerja hanya berdasarkan pada penilaian kerja dan hasilnya saja. Diharapkan pada penelitian selanjutnya dapat lebih mendalam mengenai produktivitas kerja. 


\section{DAFTAR PUSTAKA}

Almigo, Nuzsep. Hubungan Antara Kepuasan Kerja dengan Produktivitas Kerja Karyawan. Vol 1 No 01. Universitas Bina Darma, Palembang. 2004.

Alwi, Syafaruddin. Manajemen Sumber Daya Manusia, Strategi Keunggulan Kompetitif (Edisi Pertama). BPFE-Yogyakarta, Yogyakarta. 2001.

Al Fajar Siti dan Tri Heru. Manajemen Sumber Daya Manusia Sebagai Dasar Meraih Keunggulan Bersaing. UPP STIM YKPN, Yogyakarta. 2010.

Ancok, Djamaluddin. Manajemen Sumber Daya Manusia (MAP). 2001.

Arikunto, Suharsimi. Prosedur Penelitian: Suatu Pendekatan Praktik, cetakan 13. Rineka Cipta, Jakarta. 2006.

As'ad, Moch. Psikologi Indistri. Edisi Keempat. LIBERTY. Yogyakarta. 2008.

Darmayuda, I Nyoman. Analisis Produktivitas Kerja Pemasar. Skripsi. Universitas Janabadra, Yogyakarta. 2002.

Gitosudarmo, Indriyo. Manajemen Personalia. Edisi keenam. Erlangga. Jakarta.1990.

Hasibuan, Melayu, S.P. Manajemen Sumber Daya Manusia, Edisi Revisi. PT. Bumi Aksara, Jakarta. 2008.

Heidrachman dan Suad Husnan. Manajemen Personalia. Edisi Keempat. BPFE. Yogyakarta. 1990.

J. Moleong, Lexy. Metode Penelitian Kualitatif. Remaja Rosdakarya, Bandung. 2004.

Muchdarsyah, Sinungan. Produktivitas Apa dan Bagaimana, Edisi Kedua. Bumi Aksara, Jakarta. 1995.

Nawawi, Hadari. Perencanaan SDM Untuk Organisasi Profit Yang Kompetitif. Gadjah Mada University Press, Yogyakarta. 2001.

Siagian, Sondang P. Manajemen Sumber Daya Manusia. Rineka Cipta, Jakarta. 2009.

Simamora, Henry. Manajemen Sumber Daya Manusia, Edisi Kedua. STIE YKPN, Yogyakarta. 2006.

Sugiyono. Metode Penelitian Bisnis. Cetakan Pertama. CV.Alfabeta. Bandung. 1999.

Sugiyono. Metode Penelitian Kuantitatif, Kualitatif dan RED. CV. Alfabeta. Bandung. 2009.

Soeratno, dan Arsyad, Lincolin. Metodologi Penelitian Untuk Ekonomi dan Bisnis, cetakan 5. YKPN, Yogyakarta. 2008.

Triandaru, Sigit dan Totok Budisantoso. Bank dan Lembaga Keuangan Lain. Salemba Empat, Jakarta. 2006.

http://bajlife.co.id

http://jurnal-sdm.blogspot.com/2009/07/produktivitas-kerja-definisi-dan.html

http://massofa.wordpress.com/2008/04/02/pengertian-dan-faktor-faktor-yang-

mempengaruhi-produktivitas-kerja/

Ahmad

Yunadi

238

http://id.wikipedia.org/wiki/Kepuasan_Kerja

JURNAL EKONOMI SYARIAH INDONESIA, Volume II, No.2 Desember 2012 